\title{
BUBBLES OR CYCLES? HOUSING PRICE DYNAMICS IN CHINA'S MAJOR CITIES
}

\author{
Jing LI (D) 1, Yigang WEI (D) 2,3,*, Yat Hung CHIANG (D) 4 \\ ${ }^{1}$ Department of Geography and Resource Management, Chinese University of Hong Kong, Hong Kong, \\ China \\ ${ }^{2}$ School of Economics and Management, Beihang University, Beijing, China \\ ${ }^{3}$ Key Laboratory of Complex System Analysis, Management and Decision (Beihang University), Ministry of \\ Education, Beijing, China \\ ${ }^{4}$ Department of Building and Real Estate, Hong Kong Polytechnic University, Hong Kong, China
}

Received 28 January 2019; accepted 16 September 2019

\begin{abstract}
Based on the monthly data of 35 cities during the period 2006-2017, this study adopts a recursive forward looking method to detect the presence of housing bubbles and investigate their potential cyclical patterns in China's large and medium sized cities. Empirical results show that the number of cities reporting housing bubbles has been increasing since 2013, before it declined in 2017. Regarding regional disparities of housing bubbles, 1st-tier and 1.5-tier cities have higher probability than 2nd-tier cities for housing bubbles. In general, eastern region cities have more housing bubbles than central and western region cities, which may indicate the problem of shrinking cities China is facing nowadays. Bubble signals for market correction in major cities and municipalities seemed alarming in particular for the period 2013-2016, however it is difficult to conclude if the market adjustment in 2017 indicates a cyclical pattern.
\end{abstract}

Keywords: housing bubble, price-to-rent ratio, turning point, cyclical adjustment, regional disparities, China.

\section{Introduction}

Since 1998, particularly during the period from 2003 to 2017, China experienced an extensive, fast, and continuous boom of housing prices (see Figure 1). The rise of housing price is more significant in first-tier metropolises than other cities. The overheated real estate market has aroused substantial public concerns (e.g. Wei, Huang, Li, \& Xie, 2016). On the one hand, comments and forecast on the presence of housing bubbles in China have proliferated in the last decade. On the other hand, there is increasing debate whether the market is facing a turning point for cyclical adjustment, due to the obvious surge of housing prices within such a short period of time. In 1999, the average housing prices was only 2053 RMB Per Square meter, whilst it increased to 6792.55 RMB Per Square meter in 2015 with an annual growth rate of over $10 \%$ in real terms (Wind Database, 2016). However, the growth of housing price is much faster than individual income, with an enlarging price-to-income ratio. Based on price to income as a gauge of frothiness, Chinese housing seems expensive when compared to people's incomes.
The euphoria of Chinese real estate sector has made immense contributions to the real economy (Hui, Liang, Wang, Song, \& Gu, 2012; Lang, Chen, Chan, Yung, \& Lee, 2019), and also draws exceptional wealth effects for a variety of investment (Hui, Ng, \& Lau, 2011). This view can be fully illustrated by several official datasets. First, in 2015, China's real estate investment accounted for over one fourth of social fixed assets investment (Ren, 2016). Second, the market value of China real estate assets approximates to 250 trillion RMB in 2015, which is 4 times its Gross Domestic Product (GDP) and 6 times the market value of China's stock market (Ren, 2016). Third, estimates from different sources indicate that housing accounts for as much as $70 \sim 85$ percent of urban household's total wealth in China (Huang, 2013; Xie \& Jin, 2015). Fourth, the contribution of real estate to employment is also enormous. For example, during 2013-2014, Chinese developers built 1000 billion square feet of floor space, which supported 29 million employees in the construction industry accounting for $16 \%$ of urban employment (Glaeser, Huang, Ma, \& Shleifer, 2016). Fifth, according to the People's Bank

${ }^{*}$ Corresponding author. E-mail: weiyg@buaa.edu.cn 
of China, total real estate-related loan, including development loan and consumer mortgage debt, amounted to 2.1 trillion RMB in 2015 , accounting for $22.36 \%$ of the total loan. Moreover, the incremental real estate-related loan contributed to $30.6 \%$ of the overall increase of China's loan balance (The People's Bank of China [PBC], 2016). It indicates a high-risk business since "real estate investment can leave a gaping hole in bank balance sheets when things go sour" (Glaeser, 2013, p. 39). Last but not least, the fiscal status of Chinese government at different levels generally shows a heavy reliance on the revenues from the real estate industry. According to statistics, there have been more than over 40 types of taxes and fees imposed on commercial housing developers (Wei, Lam, Chiang, Leung, \& Seabrooke, 2014), such as stamp duty, urban construction and education surcharge etc. (Tang, Wong, \& Liu, 2011). In various years, revenues from land transactions contribute to over $40 \%$ of the fiscal revenue of some local governments (Wu, 2015; Lang, Long, \& Chen, 2018; Zhu, Li, Wei, Zheng, \& Xie, 2019).

Variations on housing prices are of great importance for not only the wealth of families and corporations, but also for the economy as a whole. Fluctuations in housing prices would cause or reinforce the changes in the economy. The busts of housing bubbles in Japan in 1990s and in U.S. in 2008 have resulted in property price collapse and their economies were badly hit (Hui \& Yue, 2006; Wei, Lam, Chiang, \& Leung, 2014; Lang, Radke, Chen, \& Chan, 2016). The incidences illustrate the close relationship between housing market and the macro-economy.

This paper is motivated to detect the presence of housing bubbles in the past years in China, in order to: (1) investigate the patterns and characteristics of bubbles if they occur; (2) measure the regional differences of bubble performance across the national housing market; (3) distinguish rational and irrational bubbles; (4) explore if the housing market will experience cyclical adjustments.

The rest of paper is arranged in the following manner. Section 1 provides an extensive literature review on housing bubble research. Section 2 describes the data and method. In Section 3, empirical results are presented and discussed. The major findings are summarized in the last section.

\section{Literature review}

What is definition of a bubble? Under what situations are price anomalies recognized as a bubble? How are the characteristics or formulation pattern of a price bubble measured? This section provides an extensive literature reviews on these key issues.

\subsection{Definition of bubbles}

Kindleberger (1978) defined a price bubble as "a nonsustainable pattern of price changes or cash-flows (p. 25)". Market observations that surges in asset prices are often significantly higher than changes in dividends has drawn the attention of Shiller (1981). Since then, a growing number of studies have argued that fluctuations of asset prices are jointly determined by irrational exuberance and market fundamentals (e.g. Barberis, Huang, \& Santos, 2001). However, asset-pricing literature has reiterated the great difficulties of confirming the occurrence of bubbles (e.g. Flood \& Hodrick, 1990).

A key research question of these papers refers to the high transaction costs and short-selling limits, which adds the likelihood of price diverging from fundamentals (Glaeser, Gyourko, \& Saiz, 2008). Housing often constitutes a large weight for most households' asset portfolio (Tasi \& Peng, 2011), and its characteristics are greatly distinct to what prevails in financial markets (Black, Fraser, \& Hoesli, 2006). Housing bubbles have been a hot theme for academia and investors, since forecasting housing price trend (Case \& Shiller, 1989) and seemingly great divergence between housing prices and fundamentals indicate potential arbitrage opportunities.

"Bubbles refer to asset prices that exceed an asset's fundamental value because current owners believe they can resell the asset at an even higher price" (Brunner-

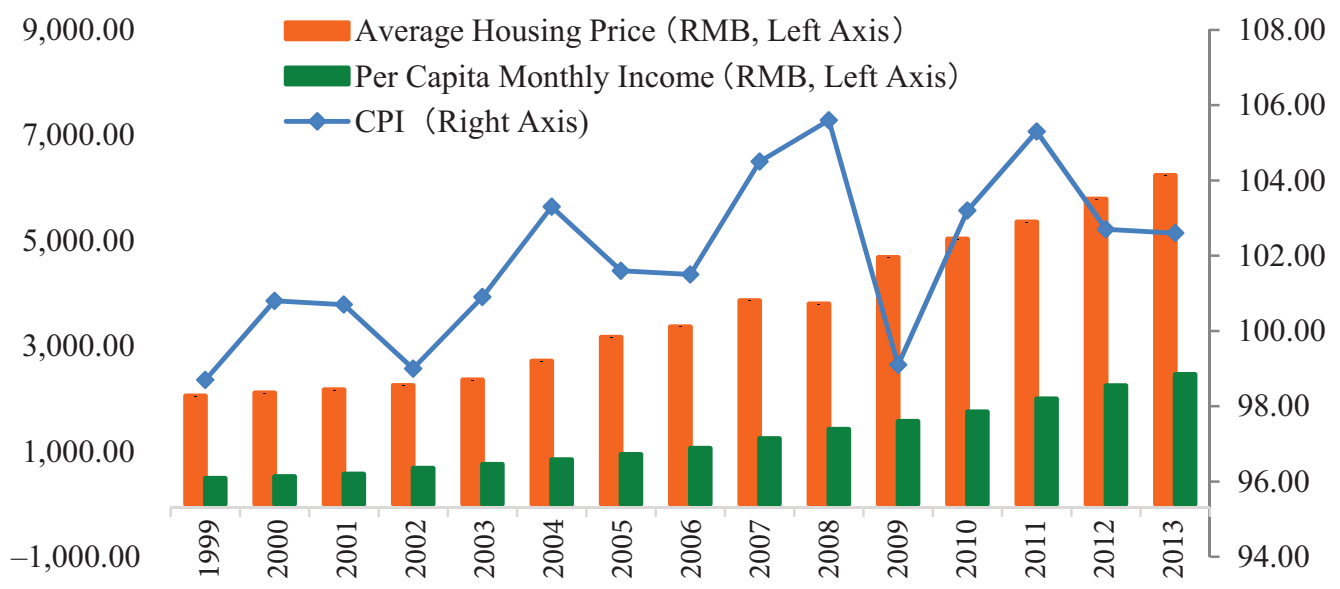

Figure 1. China's CPI, national average housing price and per capita monthly income 1999-2013 (source: Wind Database, 2016) 
meier, 2008, p. 578). Housing bubble is also defined as discrepancies between market real and expected housing price with reference market fundamentals (Hui \& Shen, 2006). According to these definitions, the emergence of housing bubbles can be identified when the market price levels virtually deviate from the housing fundamental values (Mikhed \& Zemčík, 2009). In real life, housing prices, like many other assets, show relatively high volatility compared with changes in market fundamentals (Glaeser et al., 2008). Though such definitions of housing bubbles seem clear and explicable, it is not as straightforward as it appears primary because "fundamentals" is a vague and controversy concept (Lind, 2009). The key consideration for asset pricing is whether asset prices move towards and reflect their intrinsic value (Hui, Wang, \& Wong, 2014). However, the substantial literature regarding China's housing bubbles blurs the housing bubble definition, by treating strong and quick upward movements of housing prices, high vacancies rates, large real estate investment as the signals of housing bubbles. These practices ignore measuring the fundamental housing values (Yu, 2011).

\subsection{Theoretical underpinnings of housing bubbles}

Three main concepts are available for assets bubbles i.e. explosive, intrinsic, and momentum (Black et al., 2006). They form the theoretical underpinnings for asset bubble research. Momentum denotes the irrational bubble theory, and the other two constitute rational bubble theory. In terms of the varied features of each housing bubble episode, historical episodes can be grouped to two "ideal types" of bubbles, i.e. rational bubbles and irrational bubbles, where specific mechanism dominates (Yu, 2011).

Rational bubble theory is based on the efficient market hypothesis, which implies the use of the expected presentvalue model to estimate the fundamental value. It holds that even if investors have been conscious of the overvalued assets price, they are reluctant to leave the market since they expect that bubble components will grow and compensate them appropriately (Pitros \& Arayici, 2016). Explosive and intrinsic rational bubbles constitute evidence of rationality. The difference between them is illustrated as follows. First, with an explosive rational bubble, price deviations from fundamentals are caused by factors extraneous to asset fundamental value; whereas with an intrinsic rational bubble, all variability is triggered by endogenous factors rather than exogenous factors. Second, explosive rational bubble usually shows continuous divergence and cannot be negative because otherwise it would suggest a negative asset value (Diba \& Grossman, 1988), whilst intrinsic ones do not continuously diverge but periodically revert to their fundamental value (Black et al., 2006). In other words, intrinsic bubbles usually end up as property cycles.

Statistical methods are the main measures for detecting rational bubbles, including the unit root test, cointegration test, the qualitative test, the duration test and the regime-switching test (Yu, 2011). Cointegration test is used to check the existence of bubble by probing whether there exist a stable and long-run equilibrium relationship between housing price and key fundamental variables (Hui \& Wang, 2014). However, statistic tests show several limitations. First, they remain ineffective for diagnosing irrational bubbles. Second, they cannot provide insights to the size of bubbles. Third, Evans (1991) pointed out a key defect of the use of unit root test and cointegration test in detecting housing bubbles. By means of Monte Carlo simulation, he found that these two methods are only suitable for detecting long-term bubbles, but might generate misleading conclusion for the short-dated and cyclical bubbles. In addition, these two methods are also unable to quantify the housing bubbles (Hui et al., 2014).

Irrational bubble theory does not emphasize the use of present-value model to track bubbles. Irrational bubble theory holds that investors do not pay sufficient concerns on fundamental values, but follow adaptive expectations when they estimate future price. Shiller (2013) argued that an irrational bubble is the result of social psychology (a peculiar kind of overoptimistic or epidemic) coupled with imperfect news media and information channels. It reveals some characteristics of irrational bubbles: First, the absence of complete information is usually found in the marketplace. Second, there is a degree of herd behavior that investors are more inclined to behaviors of other market participants to make decision. Third, irrational expectations are important determinant for arbitrage mechanisms since the effects of irrational transactions often exists mainly due to high transaction costs, information asymmetry, and risks (Shleifer \& Vishny, 1997). Most investors are of bounded rationality. In addition, arbitrage mechanism is not always effective to weed out the influence of irrational transactions. Thus, irrational bubbles theories dedicate a special emphasis on momentum trading behavior. Momentum investment behavior is attracted by price fluctuation alone, following the pattern of buying after price increase and selling after price decrease (Barberis, Shleifer, \& Vishny, 1998). The opportunity of momentum occurs when the marketplace is expecting the future market price will maintain current price change trajectory (either increase or decrease). For housing market, irrational expectation may take larger effects for rational arbitrage, mainly due to the higher transaction costs and information asymmetry than equity or other assets market (Meese \& Wallace, 1994). Therefore, to distinguish the irrational and rational bubbles are of significant theoretical and practical meanings.

\subsection{Methods for bubble studies}

Many scholars have reinstated the difficulty of detecting housing bubbles. For example, Gurkaynak (2008) argued that it is hardly possible to use a small sample to differentiate asset price bubbles from "time varying or regimeswitching fundamentals". Regression-based fundamental 
value model is a main approach to detect housing bubble phenomenon (Pitros \& Arayici, 2016). The underlying rationale is to compare housing market price with its fundamental price, which is determined by an array of market explanatory variables. The increase of housing prices is rooted in the improvements of fundamentals. If the increase of housing prices is not in line with market fundamentals, the existence of bubbles is detected. This strand of study probing the Chinese market is popular. By investigating the interactions between housing price with market fundamental variables, Hui and Shen (2006) measured the housing bubbles in Hong Kong during 1990 and 2003, since Hong Kong has experienced the burst of a huge housing bubble in 1997. By means of a regression model on housing price determinants, the magnitude of bubble is quantified with reference to the discrepancies between the real and predicted prices. By means of vector error correction model (VECM), Hui and Wang (2014) tested the housing prices of two popular metropolises, Beijing and Shanghai, during 1998-2012. While price anomalies occasionally happened, housing price in these two cities generally maintained reasonable levels based on market fundamentals. In addition, some recent studies have introduced both supply- and demand- side variables to investigate how the different combination of housing variables will affect the price levels, such as Goodman and Thibodeau (2008) and Coleman IV, LaCour-Little, and Vandell (2008) for the US market. The error terms of each regression test is defined as the bubbles. For example, building on the view that supply inelasticity is a key determining factor for the magnitude and duration of bubbles, Glaeser et al. (2008) constructed a detection model of housing bubbles in U.S., by incorporating housing supply into measurement. The novel model is adequate to distinguish bubble characteristics from the places with elastic and inelastic housing supply. The findings reveal that regional markets with larger elasticity of housing supply experienced shorter and smaller bubbles.

From the perspective of a policy-maker, the most important value of bubble study refers to the predictability of bubbles. A bubble indicator system collects a set of bubble characteristics to indicate the probability of a period that a bubble exists or is going to bust ( $\mathrm{Li}, 2007)$. The commonly selected indicators include interest rate as measure of housing expenditure (McCarthy \& Peach, 2004), housing supply (Glaeser et al., 2008), price/income ratio (see Case \& Shiller, 2003; Himmelberg, Mayer, \& Sinai, 2005), rentprice ratio (Taipalus, 2006), construction costs, and population. With hindsight, explanatory variables for housing bubble measurement should be numerous. As argued by Shiller (1992), housing price determinants are far more complicated and unknown than they are for other asset, which raises great difficulties for using a regression-based fundamental value model. The major defects of this method are serious. First, each regression analysis is based on unique assumptions of market explanatory variables such as mortgage rates, income etc., which might lead to er- rors in residuals and misguiding results (Hui et al., 2012). Second, the key variable of price-to-income ratio is much likely to be collinear with other variables in the regions.

Another popular method is the use of present value i.e. to discount future cash flows, such as dividend, rental revenue, to test whether the market price is equal to the flow of future earning by owning the house. High housing price relative to earning indicates candidate bubbles. See e.g. Campbell and Shiller (1988) and Bourassa, Hoesli, and Oikarinen (2019). However, there are three serious drawbacks: First, it is hard to accurately forecast future rental revenues, since they may change over time due to the effects by macro conditions, such as GDP, demographic growth. Second, it is also difficult to select a proper discounting rate for housing assets (Ren, Xiong, \& Yuan, 2012). Third, data limitation of measuring rents is another challenge. Case and Shiller (1989) stated, "we see no way of obtaining an accurate historical time series on implicit rents of owner-occupied homes". Most studies have collected housing rent data by using their own calculations-transformations, from unofficial or unreliable sources (i.e. housing agents), or with small sample (Pitros \& Arayici, 2016).

Some studies employ statistical means to test whether bubble exist, avoiding directly measuring the housing bubbles (e.g. Hong, Xi, \& Gao, 2007). Cointegration test is a popular method. Diba and Grossman (1988) argued that if several time series with a unit root are cointegrated, a linear combination of these series are stationary, which suggests all series converge to an equilibrium relationship. Therefore, the existence of a bubble would be revealed by the statistic findings of no equilibrium relationship as mentioned above. For example, Clark and Coggin (2011) used cointegration test to examine the statistical relationship between housing price and fundamental market variables in U.S. during 1975-2005. Finding suggests that housing price and fundamental market variables are unit root series but not cointegrated, even after allowing for structural breaks. However, statistical tests are incapable of measuring the size of bubbles. That is to say, such streams of studies only derived a conclusion on whether there exists housing bubble. In addition, nearly all the statistical analyses assume that bubbles are rational, thus discarding the possibility of irrational bubbles (Yu, 2011).

The abovementioned literature traditionally focuses on the relationship between real estate prices and key market fundamental variables. Recent studies have detected housing price bubbles by tracking the changed points in real estate price series. For this strand of literature, the trajectory of housing price is a major concern. The underlying logic is that the jump points in housing price time series dataset signify the key changes in trend of price growth. Jump points signify structural changes of the market. The events often involve important political and economic issues. Abrupt changes and the like refer to the movements of system parameters that occur instantly or rapidly in the sampling period. Abrupt changes include not only changes 
with large magnitudes but also small changes. Observed measurements often involve a mixture of information regarding both structural changes and the perturbations in response to the changing environment. Therefore, to track abrupt changes is not as evident as expected. As such, this philosophy for bubble detection has drawn substantial attentions in academia, and various econometric tools have been developed for detections in practical applications. The study of the detection of abrupt changes or jump points has drawn much attention from researchers. Various approaches have been devised for the detection in practical applications. Therefore, to properly identify such jump point provides predictive evidence for investors and policy-makers. For example, Hui, Carisa, and Ip (2010) used a wavelet analysis to detect the jump points in housing price of Hong Kong. The findings revealed that the jump points somehow indicated millstone events or key political or economic issues. However, since the number of jump points is determined by the threshold value, inappropriate selection of threshold value for the wavelet coefficients may lead to misleading findings. Based on GSADF test, it is found that from the period of 1998 to 2013 a few major Chinese cities had bubble signals (Tsai, Kung, \& Haga, 2015; Liu, 2016).

\subsection{Importance of bubble research}

Existing literature reports that the presence of bubbles was confirmed in some market (for example, Mikhed \& Zemčík, 2009 for the US; Zhou \& Sornette, 2003 for the UK; Fernández-Kranz \& Hon, 2006 for Spain; Hui et al., 2012 for Hong Kong). Are there housing bubbles in China? To what magnitude do the bubbles, if any, exist? Researchers have generated a dizzying array of findings and views on these key issues. There have been many attempts to detect the presence of housing price bubbles in different Chinese cities. However, most of these studies focus on a limited number of cities, such as Beijing, Shanghai, and Hong Kong. For example, Hong Kong is an epicenter of housing bubble, which is a popular city for studies on China's housing bubbles. There are certain common generative patterns for the formation of housing bubbles, including the influx of speculative capital, limited channels for investment (Hui \& Ng, 2009). Yet, the existence of housing bubbles in China is far from being certain.

The importance of housing bubble research is warranted for at least four reasons. First, housing has been shown greater wealth effects than other assets (Benjamin, Chinloy, \& Jud, 2004). Second, housing usually contributes the largest weight for asset portfolio of most families (Englund, Hwang, \& Quigley, 2002). Third, market hindsight indicates that the busts of housing bubbles have much larger damages on the economy than stock busts. For example, Helbling and Terrones (2003) reported that given a less frequent occurrence, the output loss associated with housing busts were around twice as large as those associated with equity price busts, reflecting property market's greater shocks on banking and consumption sectors, which are under heavy exposure to housing. Fourth, since most housing transactions are conducted for the purposes of consumption rather than investment, and also because of some unique attributes of housing market such as "high transaction costs, heterogeneity, and illiquidity", opportunities for rational arbitrage is limited and thus the process of correcting price towards "real" value is likely to be prolonged (Black et al., 2006, p. 1536).

\section{Data and method}

The data sets employed in this study include 26 provincial and autonomous regional capitals, 4 municipalities and 5 medium-large sized coastal cities. The data is sourced from the website of National Bureau of Statistics of China (http://data.stats.gov.cn/easyquery.htm?cn=A01). The data of the monthly housing price is directly retrieved at the city level, based on the primary market transactions. The data of monthly housing rent is compiled from the monthly composition of consumer price index, which consists of housing expenditure in terms of rent. City level priceto-rent ratio in logarithm is compiled for bubble testing, covering the period of January 2006 till December 2017.

Based on the present value model, rational bubble assumption and nonlinear explosive characteristics, Yiu and Jin (2012) devised a method to explore the potential bubble existence in asset prices of sub-samples under flexible initial observation and window size. The Right-tailed Augmented Dickey-Fuller (RADF) method assumes a random walk process as follows:

$$
y_{t}=d T^{-\eta}+\theta y_{t-1}+\varepsilon_{t}, \varepsilon_{t}(i i d) \sim N\left(0, \sigma^{2}\right), \theta=1
$$

where: $d$ is constant; $\eta$ is a localizing coefficient of the sample size $T$ which approaches infinity and $\varepsilon$ is the error term. The testing strategy of RADF is based on the following equation:

$$
y_{t}=\mu+\rho y_{t-1}+\sum_{1}^{p} \phi_{i} \Delta y_{t-i}+\varepsilon_{t},
$$

where: $y$ is the variable for question; $\mu$ is an intercept; $p$ is the maximum number of lags; $\varepsilon$ is the error term. The RADF test examines the null hypothesis of a unit root and the alternative hypothesis of an explosive autoregressive coefficient:

Null Hypothesis $H_{0}: \rho=1$;

Alternative Hypothesis $H_{1}: \rho>1$.

Unlike the left-tailed Augmented Dickey-Fuller test whose alternative hypothesis is stationary, the RADF test in Equation (3) and (4) assume the explosive pattern of asset price. The innovation of the RADF test is that its Dickey-Fuller statistics is calculated in a forward recursive way: the number of observations used in each regression expands until full sample data is used. This arrangement facilitates the RADF test to proceed in a forward recursive way to identify the origination and collapse dates of a bubble, according to the critical value sequence. To begin with, the first recursion has $\tau_{0}=\left[n r_{0}\right], r_{0} \in(0,1)$ observations at the initial period. Subsequent recursions employ 
this initial data set, which is supplemented by successive observations with a sample size $\tau=[n r], r_{0} \leq r \leq 1$. When $\rho$ is equal to or larger than the right side critical value of the RADF test the bubble initiates, when the t-statistic drops back to or below the critical value the bubble collapses.

The original application of RADF to housing price bubble has a limitation (Yiu, Yu, \& Jin, 2013): the conclusion of bubble existence becomes ambiguous when both housing price and housing rent exhibit presence of explosive features in the same period. Hence to avoid such ambiguity, the price-to-rent ratio is utilized. In the Table 1 and Figure 2, it displays the bubble detection results of all 35 cities from 2007 to 2017. The green curve stands for the original price-to-rent ratio in logarithm. The red curve stands for $99 \%$ critical value sequence as identified by recursion. The blue curve stands for rolling Augmented Dickey-Fuller (ADF) statistics. If rolling ADF value is above the critical value, it suggests that a housing bubble is recorded. When rolling ADF value drops below the critical value, it suggests that a housing bubble collapses.

A major merit of the RADF method for bubble detection is that it recursively figures out the irrational element of bubble formation. Therefore, to improve the predictability of potential housing bubble collapse as irrational bubbles is more crucial than rational bubbles in determining the time of property price adjustment. In the context of our study period, using a method which can detect the irrational bubble element is of particular importance, as not all of the price increases in China's housing market are regarded as rational in previous studies (Hou, 2010; Yu, 2011; Lin \& Tsai, 2016). Adopted by the Fed Reserve St. Louis too, the RADF method excels in the accurate and timely detection of equity bubble collapse in the stock and property markets. The method is in contrast with traditional studies, which computes fundamental values by means of an equilibrium model including variables such as interest rate, construction cost, and household incomes etc. The RADF method is a versatile tool for detecting irrational equity bubbles, derived from stock market empirics but with great potential for real estate research. Given a larger number of macro controls that have been imposed on China's housing market in the last decade, there is still a paucity of studies on policy effects on the market. This study tries to contribute knowledge on this field. The RADF method differentiates bubble components into long-term and short-terms ones, and accounts for the existence of rational and irrational bubbles. An insight to the different bubble features and their driving forces from fundamental values is particularly valuable for understanding whether the market will experience cyclical pattern, which typically follows a market collapse.

Various previous studies have used panel data regression to study the determinants of housing prices in China. Liu and Shen (2005) investigated the macroeconomic variables affecting housing prices in China from 1986 to 2002. They found that unemployment rate, population, changes in construction cost and CPI Granger caused housing prices, with feedback effects from vacancy rate, changes in household disposable income and CPI. Zhang, Hua, and Zhao (2012) adopted non-linear auto-regressive moving average with exogenous inputs model to study the determinants of China's monthly housing prices from January 1999 to June 2010, and found that influential variables include mortgage rate, producer price, $\mathrm{M} 2$ and real effective exchange rate. Wang, Chan, and $\mathrm{Xu}$ (2012) studied the price elasticity of 35 Chinese cities from 1998 to 2009, and indicated national supply elasticity was between 2.8 and 5.6. Choy and $\mathrm{Li}$ (2017) found that $1 \%$ increase of population share with university education or above will jet up the housing prices by $0.873 \%$, based on provincial level data from 1998 to 2015. These studies have looked into different factors affecting housing prices, however, less is known about the existence and disparity of housing bubbles in China, as panel data regression usually comes up with aggregate results only.

The focus of this study is to reveal the regional disparity of housing bubbles in large and middle sized cities, based on RADF method. The beauty of using price-to-rent ratio for testing bubble is that it resembles the price-toearnings $(\mathrm{P} / \mathrm{E})$ ratio in the stock market which can reflect the explosive patterns of bubbling period, which is better than simply using the housing price to indicate market irregularity. The major reason we chose price-to-rent ratio instead of price-to-income ratio is that income is only available on a quarterly basis. To ensure the study period to be as long as possible to better capture the effects of trends and structural changes, we prefer to use price-torent ratio.

\section{Discussion of results}

According to Table 1, the price-to-rent ratios of 6 major cities and municipalities (Beijing, Shanghai, Guangzhou, Shenzhen, Chongqing, and Tianjin: the former four are referred to as 1st-tier cities; the latter two together with Chengdu, Wuhan, Nanjing and Xian are referred to as 1.5-tier cities; while the rest of the 35 cities are referred to as 2nd-tier cities) experienced upward movements from 2006 to 2009, with Beijing and Shenzhen showing housing bubbles. Except for Beijing and Guangzhou from 2009 to 2010, other major cities did not have signs of housing bubbles lasting over three months in this period. From 2010 to 2012, the six major cities and municipalities had unanimous price-to-rent ratio adjustment, which may be due to the government's restrictions on home purchase and bank lending (Sun, Zheng, Geltner, \& Wang, 2017; Du \& Zhang, 2015; Li \& Xu, 2016; Li, Cheng, \& Cheong, 2017). Since 2013, the price-to-rent ratios in these megacities have picked up again probably because the implementation of home purchase restriction became less strict, leading to intense housing bubbles with longer durations.

Several interesting findings arise from Table 1. First, the "Four-Trillion RMB Fiscal Stimulus Package" introduced in 2009 seems to have an immediate impact on housing bubble creation in Beijing (though not lasting 
Table 1. Summary of housing bubble periods in all cities

\begin{tabular}{|c|c|c|c|c|c|c|c|c|c|}
\hline City & Beijing & Changchun & Changsha & Chengdu & Chongqing & Dalian & Fuzhou & Guangzhou & Guiyang \\
\hline $\begin{array}{l}\text { Bubble } \\
\text { periods }\end{array}$ & $\begin{array}{l}\text { Nov 08-Jan } 09 \\
\text { Nov 09-Apr } 10 \\
\text { Apr 13-Apr } 14 \\
\text { Aug 16-Nov } 16 \\
\text { Aug 17-Dec } 17\end{array}$ & 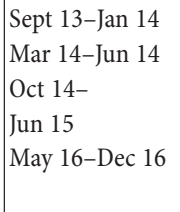 & \begin{tabular}{|l} 
Oct 07 \\
Jan 08 \\
Mar 10 \\
Jul 13-Apr 14 \\
Oct 14-Nov 14 \\
Sept 16-Dec 16
\end{tabular} & $\begin{array}{l}\text { Oct } 12 \\
\text { Sept 13-Apr } 14 \\
\text { Nov 14-Apr } 15 \\
\text { Aug 16-Oct } 16 \\
\text { Aug 17-Sept } 17\end{array}$ & $\begin{array}{l}\text { Oct } 07 \\
\text { Sept } 13-\text { Apr } 14 \\
\text { Oct 14-May } 15 \\
\text { Sept 16-Jan } 17\end{array}$ & $\begin{array}{l}\text { Nov } 08-\text { Dec } 08 \\
\text { Oct 13-Mar } 14 \\
\text { Oct 14-May } 15\end{array}$ & $\begin{array}{l}\text { Jun 13-Mar } 14 \\
\text { Nov 14-Apr } 15 \\
\text { Aug 16-Feb } 17\end{array}$ & $\begin{array}{l}\text { Sept } 08 \\
\text { Dec } 09-\text { Feb } 10 \\
\text { Mar } 13-\text { May } 14 \\
\text { Aug } 16-\text { Oct } 16 \\
\text { Dec } 17\end{array}$ & \begin{tabular}{|l} 
Dec 12 \\
Oct 14-Feb 15 \\
Oct 16-Jan 17
\end{tabular} \\
\hline City & Haikou & Hangzhou & Harbin & Hefei & Hohhot & Jinan & Kunming & Lanzhou & Nanchang \\
\hline $\begin{array}{l}\text { Bubble } \\
\text { periods }\end{array}$ & $\begin{array}{l}\text { Jan } 10-\text { Jul } 10 \\
\text { Jan } 13 \\
\text { Oct } 14-\text { Dec } 14\end{array}$ & $\begin{array}{l}\text { Oct } 07-\operatorname{Jan} 08 \\
\text { Apr } 12-\text { Oct } 12 \\
\text { Oct 14-Mar } 15 \\
\text { Oct } 17-\text { Dec } 17\end{array}$ & $\begin{array}{l}\text { Aug } 13-\text { May } 14 \\
\text { Nov } 14-\text { Apr } 15 \\
\text { Sept } 16 \\
\text { Oct } 17-\text { Dec } 17\end{array}$ & $\begin{array}{l}\text { Nov } 08-\text { May } 09 \\
\text { Aug } 13-\text { Mar } 14 \\
\text { Dec } 14 \\
\text { May } 16-\text { Nov } 16\end{array}$ & $\begin{array}{l}\text { Oct 13-May } 14 \\
\text { Dec 14-Mar } 15\end{array}$ & $\begin{array}{l}\text { Oct 14-Apr } 15 \\
\text { Sept 16-Feb } 17\end{array}$ & $\begin{array}{l}\text { Feb } 09 \\
\text { Oct 14-Dec } 14 \\
\text { Jan 17-Aug } 17\end{array}$ & $\begin{array}{l}\text { Jan } 09 \\
\text { Apr 09 } \\
\text { Nov 13-Mar } 14 \\
\text { Dec 14-May } 15\end{array}$ & $\begin{array}{l}\text { Aug } 13 \text {-Oct } 13 \\
\text { Jan } 15-\text { Feb } 15 \\
\text { Aug } 16-\text { Oct } 16\end{array}$ \\
\hline City & Nanjing & Nanning & Ningbo & Qingdao & Shanghai & Shenyang & Shenzhen & Shijiazhuang & Taiyuan \\
\hline $\begin{array}{l}\text { Bubble } \\
\text { periods }\end{array}$ & $\begin{array}{l}\text { Sept 13-Mar } 14 \\
\text { May 16-Nov } 16\end{array}$ & $\begin{array}{l}\text { Jan 14-Apr } 14 \\
\text { Feb 15 } \\
\text { Oct 16-Dec } 16\end{array}$ & $\begin{array}{l}\text { Jan 08-Feb } 08 \\
\text { Nov } 09 \\
\text { Apr 12-Nov } 12 \\
\text { Nov 14-Mar } 15 \\
\text { Apr 16-Sept } 16\end{array}$ & $\begin{array}{l}\text { Dec } 08 \\
\text { Apr 12 } \\
\text { Dec 13-Mar } 14 \\
\text { Nov 14-Apr } 15 \\
\text { Sept 16-Feb } 17\end{array}$ & \begin{tabular}{|l} 
Dec $09-$ Feb 10 \\
Aug 12-Oct 12 \\
Jun $13-$ Mar 14 \\
Dec $14-$ Jan 15 \\
Sept 16 \\
Oct $17-$ Dec 17
\end{tabular} & \begin{tabular}{|l|} 
Jun $13-$ Mar 14 \\
Aug 17-Dec 17
\end{tabular} & $\begin{array}{l}\text { Jan 08-Feb } 08 \\
\text { Oct 08-Mar } 09 \\
\text { Jun 13-Apr } 14 \\
\text { Oct 15-Apr } 16 \\
\text { Jul 17-Nov } 17\end{array}$ & \begin{tabular}{|l} 
Jan 08 \\
Aug 13-May 14 \\
Dec 14-Feb 15 \\
Oct 16-Feb 17
\end{tabular} & $\begin{array}{l}\text { Feb 12 } \\
\text { Aug 13-Apr } 14 \\
\text { Nov 14-Apr } 15 \\
\text { Oct 16-Mar } 17\end{array}$ \\
\hline City & Tianjin & Urumqi & Wuhan & Xiamen & Xi'an & Xining & Yinchuan & Zhengzhou & \\
\hline $\begin{array}{l}\text { Bubble } \\
\text { periods }\end{array}$ & $\begin{array}{l}\text { Oct 09-May } 10 \\
\text { Dec 13-May } 14 \\
\text { Oct 14-Apr } 15 \\
\text { Jul 16-Feb } 17\end{array}$ & $\begin{array}{l}\text { Jan 08-May } 08 \\
\text { May 10-Jul } 10 \\
\text { Mar 13-Feb } 14 \\
\text { Jan } 15-\text { May } 15 \\
\text { Oct } 17-\text { Dec } 17\end{array}$ & $\begin{array}{l}\text { Feb 12-Apr } 12 \\
\text { Oct 14-Jan } 15 \\
\text { Feb } 17 \\
\text { Aug } 17-\text { Sept } 17\end{array}$ & $\begin{array}{l}\text { Sept 12-Jan } 13 \\
\text { Oct 13-May } 14 \\
\text { Jul 16-Dec } 16\end{array}$ & \begin{tabular}{|l} 
Jan 08 \\
Jan 10 \\
Mar 10-Apr 10 \\
Aug 13-May 14 \\
Jan 15-Mar 15 \\
Nov 16-Apr 17 \\
Jun 16-Aug 16
\end{tabular} & $\begin{array}{l}\text { Jan } 14-\text { Feb } 14 \\
\text { Oct } 14-\text { Nov } 14 \\
\text { May } 17-\text { Dec } 17\end{array}$ & $\begin{array}{l}\text { Dec } 08-\text { May } 09 \\
\text { Oct 09-Mar } 10 \\
\text { Dec 13-Apr } 14 \\
\text { Jan 15-Jul } 15 \\
\text { Oct 16-Nov } 16\end{array}$ & $\begin{array}{l}\text { Jan } 09 \\
\text { Aug 13-Feb } 14 \\
\text { Oct 16-Feb } 17\end{array}$ & \\
\hline
\end{tabular}

Note: Significant at 95\% confidence level.

long due to purchase quota), which may be due to the speeding up of infrastructure construction in both cities. In fact, Beijing has constructed a dozen of MTR lines since mid-2000s in preparation for the 2008 Olympic Games, which significantly pushed up its housing prices and expanded its urban boundary. Yet it was not until 2009 when the additional fiscal stimulus package was introduced that housing bubble signals emerged.

Second, a pilot property tax reform was announced in Shanghai and Chongqing in 2011, which aimed at charging ownership taxes for luxurious housing units. However, implementation of pilot property tax reform did not seem to contain housing bubble generation in both cities. Ironically or not, before the announcement of property tax experiment, Shanghai only had 3 months of housing bubbles while Chongqing had merely 1 month; afterwards Shanghai had 19 months of housing bubbles while Chongqing had 13 months.

Third, since 2014 all the six major cities and municipalities have exhibited signs of housing bubbles lasting for over 3 months, which may be indicative of early warning for the market adjustment. Indeed, in 2017 only Beijing, Shanghai and Shenzhen still had housing bubbles lasting for three months or more, indicating the nationwide housing market began to adjust after years of overheated market atmosphere.

Fourth, the eastern region is featured by higher population density and higher productivity levels and those of central and western regions. However, in most eastern cities, there are also increasing signs of housing bubbles compared with central and western regions, which may indicate the problem of shrinking cities China is facing nowadays. Some earlier signs were found in Hangzhou, Ningbo and Qingdao. Other cities did not show bubble signs in this period, except Nanning and Shenyang in 2007. Since 2012, increasing signals of bubbles were observed in wider range of cities. The increasing total number of cities having housing bubbles from 2014 to 2016 may be due to the relaxation of home purchase quota in China ( $\mathrm{Li} \& \mathrm{Xu}$, 2016). Previous studies have demonstrated that cities in the eastern region have more housing pressures than those in the western regions, due to the demographic clustering effect for the coastal regions and the hollowing-out effect for the inland regions population movement $(\mathrm{Li}, \mathrm{Xu}, \&$ Chiang, 2014; Choy \& Li, 2017). The findings also echo previous literature that eastern regions have more severe housing bubbles (Dreger \& Zhang, 2013).

Figure 2 has grouped metro areas with similar bubble periods. It is noteworthy that from 2013 to 2014, intense housing bubbles are observed in majority of cities. However, the average length of housing bubbles became shorter from 2014 to 2016, although the frequency of housing bubbles increased. Since 2017 both the length and frequency of housing bubbles significantly declined. Such change has two important research implications.

On the one hand, more cities tend to have housing bubbles since 2013. When compare such trend with the performance of China's stock market, it is interesting to 
2007/10/1 2009/2/12 2010/6/27 2011/11/9 2013/3/23 2014/8/5 2015/12/18 2017/5/1

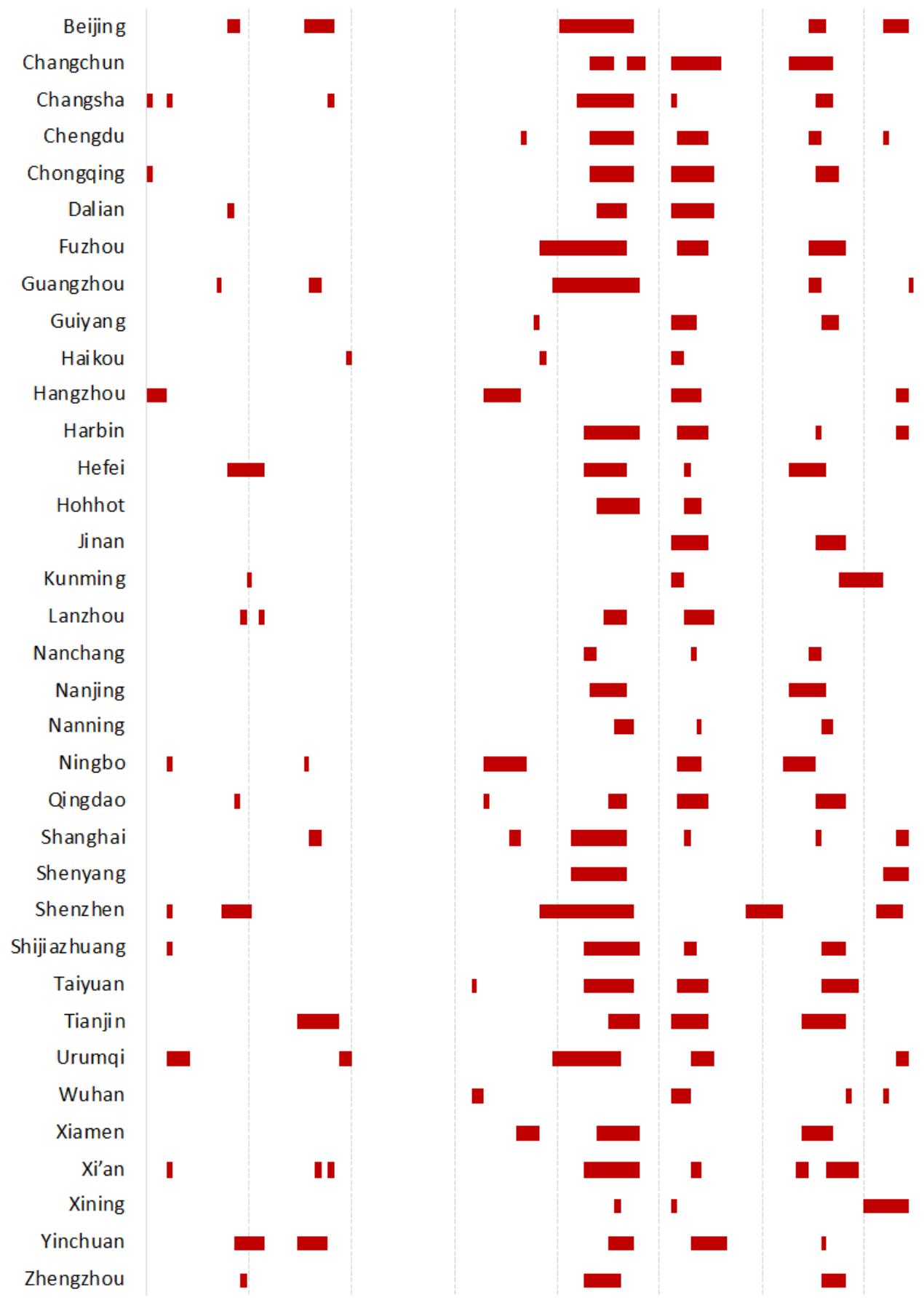

Figure 2. Timeline of housing bubbles across cities

find out that China's A-share market boom (between mid2014 and mid-2015) seemed to follow the property market boom (with intense and long-lasting housing bubbles between mid-2013 and mid-2014). The logic seemed that investors retreated from the housing market after lock-in their profits (as housing bubbles had shorter durations since then) and shifted their capitals into the stock market.

On the other hand, although the number of housing bubbles decreased in 2017, it is difficult to conclude if the housing market is facing a property bust. In 2017, 11 out of 35 cities still had housing bubbles, including three first- tier cities: Beijing, Shanghai and Shenzhen. Unlike the period 2014-2015, China's stock market did not perform well afterwards, and the exchange rate of RMB to USD has been volatile since then. Thus it is difficult to judge whether capital is inflowing or outflowing China's housing market.

It is noteworthy that there might be connections between Chinese city housing markets, thus the systematic links between these markets which might have impacts on housing bubbles in China should not be ignored. Shih, $\mathrm{Li}$, and Qin (2014) analyzed the potential contagion and 
spillover effect of housing bubbles in 28 Chinese provinces between 2000 and 2012, and found that most provinces had housing bubble and affordability problems while those within the same contagious region were cointegrated. Yu (2015) adopted the global vector autoregression model to study the spillover effect of housing prices in 35 major Chinese cities, and found that first-tier cities such as Beijing and Shanghai had relatively larger spillovers of housing prices. Yu and Huang (2016) further demonstrated the positive impact of housing price shocks from first-tier cities and eastern cities to housing price increase in central and western cities. Weng and Gong (2017) revealed strong co-movement and volatility spillover of housing prices in regions with similar geographic and economic proximities. Yang, Yu, and Deng (2018) studied 69 major Chinese cities and observed high interaction among city-level housing prices, with systematically important cities agglomerating in five concentrated areas. Our findings primarily echo these literatures in that coastal regions tend to have higher signs of housing bubbles than inland regions, and price correction seemed to be taking place in first-tier cities in recent years.

\section{Conclusions}

China is now an ideal place for testing whether there is a nationwide housing bubble or property cycle. Some previous studies argue that high homeownership rates, increasing vacancy rates, rapidly growing housing mortgage loans, escalating land prices and fast rising housing prices are signals of housing bubbles (Yu, 2011; Wu, Gyourko, \& Deng, 2012; Lin \& Tsai, 2016; Zhu, Zhang, Wei, Li, \& Zhao, 2019). Others claim that robust wage growth, high saving rate, rapidly increasing urbanization, low leverage of home financing and rising middle income households with limited investment vehicles underpin China's property boom (Wei, Lam, Chiang, \& Leung, 2010; Ahuja, Cheung, Han, Porter, \& Zhang, 2010; Deng, Morck, Wu, \& Yeung, 2011; Li \& Chiang, 2012; Ren et al., 2012; Feng \& Wu, 2015; Lang, Chen, \& Li, 2016), and can be buffers to deterioration of the property market. While both views hold some truth, there is a consensus that the main drivers of China's real estate booms were excessive monetary supply, aggressive fiscal expenditure, and rapid urbanization (Shen, 2012; Zhang et al., 2012; Xu \& Chen, 2012; Li, 2013; Deng, Morck, Wu, \& Yeung, 2015; Chen, Lang, Chan, \& Phillip, 2018).

History has repeatedly demonstrated that neglecting excess property booms could be disastrous to the economy, when bust of housing bubble leads to financial market collapse. China's real estate market development heavily depends on the credit channel (Wei et al., 2014), the collateral channel (Wu, Gyourko, \& Deng, 2015), and the informal channel (Lu, Guo, Kao, \& Fung, 2015). It is therefore essential to evaluate potential housing bubbles across major cities of China. Empirical results show that housing bubbles were increasing after 2014, particularly for the period 2015-2016. Regarding regional dispari- ties of housing bubbles, coastal region cities seem to have higher probability than those in inland regions in meeting market adjustments. In general, eastern region cities may face more downward pressure for price corrections than central and western region cities. And bubble signals for market correction in major cities and municipalities seem alarming. However, we did not find strong signals of property cycles so far, as housing bubbles tend to be repetitive and persistent over time.

The disparity of housing bubbles across regions reflects important information about China's economic conditions. China has the long-standing problem of regional inequality between coastal and inland regions, as well as among large, middle and small sized cities. Fluctuations in housing prices would cause or reinforce the changes in the regional economy. Higher housing prices typically indicate higher land prices, or greater expenses for employers but higher income for employees. If the stimulating effect of higher wages for employees outweighs the counteracting effect of higher costs for employers, then income growth tends to be accelerated and sustained. As housing prices continue to increase, the benefits from incentivized employees may be gradually covered by the losses from disinterested employers. At some critical turning point, the employers may find that their business is no longer profitable due to escalating expenses. This may lead to an exit from the existing market or an outsourcing of the business to other low-cost regions.

To summarize, this paper compares the emergence of housing bubbles in 35 major Chinese cities over the period 2007 to 2017. It is striking that most cities had signs of housing bubbles in 2016. In other years the bubbles tend to be mild as the forward ADF sequence is only slightly above the 95\% critical value over time. In 2017 the number of cities with housing bubbles dropped substantially. Will such trend indicate a cyclical turning point? The question remains unanswered fully which requires further exploration. The RADF method will be adopted with more updated data in the future.

\section{Funding}

This work was supported by the MOE (Ministry of Education in China) Project of Humanities and Social Sciences under Grant [number 18YJC840041]; the National Natural Science Foundation of China under Grant [number 71904009].

\section{Author contribution}

Jing Li and Yat Hung Chiang were responsible for the design and development of the data analysis. Jing Li and Yigang Wei were responsible for data interpretation and the first draft of the article.

\section{Disclosure statement}

The authors declare no conflict of interest. 


\section{References}

Ahuja, A., Cheung, L., Han, G., Porter, N., \& Zhang, W. (2010). Are house prices rising too fast in China? (IMF Working Paper, pp. 1-31). https://doi.org/10.5089/9781455210817.001

Barberis, N., Shleifer, A., \& Vishny, R. (1998). A model of investor sentiment. Journal of Financial Economics, 49, 307-343. https://doi.org/10.1016/S0304-405X(98)00027-0

Barberis, N., Huang, M., \& Santos, T. (2001). Prospect theory and asset prices. The Quarterly Journal of Economics, 116(1), 1-53. https://doi.org/10.1162/003355301556310

Benjamin, J. D., Chinloy, P., \& Jud, G. D. (2004). Real estate versus financial wealth in consumption. Journal of Real Estate Finance and Economics, 29, 341-354.

https://doi.org/10.1023/B:REAL.0000036677.42950.98

Black, A., Fraser, P., \& Hoesli, M. (2006). House prices, fundamentals and bubbles. Journal of Business Finance and Accounting, 33(9/10), 1535-1555.

https://doi.org/10.1111/j.1468-5957.2006.00638.x

Hong, T., Xi, B., \& Gao, B. (2007). Co-movement of real estate prices and spatial diffusion of bubbles: evidence from 35 metropolis in China from 2000 to 2005. Statistical Research, 24(8), 64-67.

Bourassa, S. C., Hoesli, M., \& Oikarinen, E. (2019). Measuring house price bubbles. Real Estate Economics, 47(2), 534-563. https://doi.org/10.1111/1540-6229.12154

Brunnermeier, M. K. (2008). Bubbles. In S. N. Durlauf, \& L. E. Blume (Eds.), The new Palgrave dictionary of economics (2nd ed.). New York: Palgrave Macmillan. https://doi.org/10.1057/978-1-349-95121-5_44-2

Campbell, J., \& Shiller, R. (1988). The dividend-price ratio and expectations of future dividends and discount factors. Review of Financial Studies, 1(3), 195-227.

https://doi.org/10.1093/rfs/1.3.195

Case, K. E., \& Shiller, R. J. (1989). The efficiency of the market for single-family homes. American Economic Review, 79(1), 125-137.

Case, K. E., \& Shiller, R. J. (2003). Is there a bubble in the housing market? Brookings Papers on Economic Activity, 34(2), 299-362. https://doi.org/10.1353/eca.2004.0004

Chen, T., Lang, W., Chan, E. H. W., \& Phillip, C. (2018). Lhasa: urbanising China in the frontier regions. Cities, 74, 343-353. https://doi.org/10.1016/j.cities.2017.12.009

Choy, L. H., \& Li, V. J. (2017). The role of higher education in China's inclusive urbanization. Cities, 60, 504-510. https://doi.org/10.1016/j.cities.2016.04.008

Clark, S. P., \& Coggin, T. D. (2011). Was there a U.S. house price bubble? An econometric analysis using national and regional panel data. Quarterly Review of Economics \& Finance, 51(2), 189-200. https://doi.org/10.1016/j.qref.2010.12.001

Coleman IV, M., LaCour-Little, M., \& Vandell, K. D. (2008). Subprime lending and the housing bubble: tail wags dog? Journal of Housing Economics, 17(4), 272-290. https://doi.org/10.1016/j.jhe.2008.09.001

Deng, Y., Morck, R., Wu, J., \& Yeung, B. (2011). Monetary and fiscal stimuli, ownership structure, and China's housing market (Working Paper No. 16871). National Bureau of Economic Research. https://doi.org/10.3386/w16871

Deng, Y., Morck, R., Wu, J., \& Yeung, B. (2015). China’s pseudomonetary policy. Review of Finance, 19(1), 55-93. https://doi.org/10.1093/rof/rfu026

Diba, B. T., \& Grossman, H. I. (1988). Explosive rational bubbles in stock prices? American Economic Review, 78(3), 520-530.

Dreger, C., \& Zhang, Y. (2013). Is there a bubble in the Chinese housing market? Urban Policy and Research, 31(1), 27-39. https://doi.org/10.1080/08111146.2012.711248
Du, Z., \& Zhang, L. (2015). Home-purchase restriction, property tax and housing price in China: a counterfactual analysis. Journal of Econometrics, 188(2), 558-568.

https://doi.org/10.1016/j.jeconom.2015.03.018

Englund, P., Hwang, M., \& Quigley, J. M. (2002). Hedging housing risk. Journal of Real Estate Finance and Economics, 24, 167-200. https://doi.org/10.1023/A:1013942607458

Evans, G. W. (1991). Pitfalls in testing for explosive bubbles in asset prices. The American Economic Review, 81(4), 922-930.

Feng, Q., \& Wu, G. L. (2015). Bubble or riddle? An asset-pricing approach evaluation on China's housing market. Economic Modelling, 46, 376-383. https://doi.org/10.1016/j.econmod.2015.02.004

Fernández-Kranz, D., \& Hon, M. T. (2006). A cross-section analysis of the income elasticity of housing demand in Spain: is there a real estate bubble? Journal of Real Estate Finance and Economics, 32(4), 449-470. https://doi.org/10.1007/s11146-006-6962-9

Flood, R., \& Hodrick, R. (1990). On testing for speculative bubbles. Journal of Economic Perspectives, 4(2), 85-101. https://doi.org/10.1257/jep.4.2.85

Glaeser, E. (2013). A nation of gamblers: real estate speculation and American history. The American Economic Review, 103(3), 1-42. https://doi.org/10.1257/aer.103.3.1

Glaeser, E. L., Gyourko, J., \& Saiz, A. (2008). Housing supply and housing bubbles. Journal of Urban Economics, 64(2), 198-217. https://doi.org/10.1016/j.jue.2008.07.007

Glaeser, E., Huang, W., Ma, Y., \& Shleifer, A. (2016). A real estate boom with Chinese characteristics (Working Paper No. 22789). National Bureau of Economic Research. https://doi.org/10.3386/w22789

Goodman, A. C., \& Thibodeau, T. G. (2008). Where are the speculative bubbles in us housing markets? Journal of Housing Economics, 17(2), 117-137. https://doi.org/10.1016/j.jhe.2007.12.001

Helbling, T., \& Terrones, M. (2003). When bubbles burst. In Word economy outlook (pp. 61-94). Washington, DC: International Monetary Fund.

Himmelberg, C., Mayer, C., \& Sinai, T. (2005). Assessing high house prices: bubbles, fundamentals and misperceptions. Journal of Economic Perspectives, 19(4), 67-92. https://doi.org/10.1257/089533005775196769

Hou, Y. (2010). Housing price bubbles in Beijing and Shanghai? A multi-indicator analysis. International Journal of Housing Markets and Analysis, 3(1), 17-37. https://doi.org/10.1108/17538271011027050

Huang, Z. (2013). A study of household finance in China (Doctoral dissertation, Lingnan University, Hong Kong). Retrieved from https://pdfs.semanticscholar.org/1e08/3e553b818de258c5 e623e1b2878ee3afa52b.pdf?_ga=2.196997669.881163299. 1574068484-601170192.1535370806

Hui, E. C. M., \& Ng, I. (2009). Price discovery of property markets in Shenzhen and Hong Kong. Construction Management and Economics, 27(12), 1175-1196. https://doi.org/10.1080/01446190903365640

Hui, E. C. M., \& Shen, Y. (2006). Housing price bubbles in Hong Kong, Beijing and Shanghai: a comparative study. Journal of Real Estate Finance and Economics, 33(4), 299-327. https://doi.org/10.1007/s11146-006-0335-2

Hui, E. C. M., \& Wang, Z. (2014). Price anomalies and effectiveness of macro control policies: evidence from Chinese housing markets. Land Use Policy, 39(3), 96-109. https://doi.org/10.1016/j.landusepol.2014.04.003

Hui, E. C. M., Liang, C., Wang, Z., Song, B. T., \& Gu, Q. (2012). Real estate bubbles in China: a tale of two cities. Construction Management and Economics, 30(11), 951-961. https://doi.org/10.1080/01446193.2012.714871 
Hui, E. C. M., Ng, I., \& Lau, M. F. O. (2011). Speculative bubbles in mass and luxury properties: an investigation of the Hong Kong residential market. Construction Management and Economics, 29(8), 781-793.

https://doi.org/10.1080/01446193.2011.610329

Hui, E. C., Carisa, K. W., \& Ip, W. C. (2010). Jump point detection for real estate investment success. Physica A: Statistical Mechanics and its Applications, 389(5), 1055-1064.

https://doi.org/10.1016/j.physa.2009.11.022

Hui, E. C., Wang, Z., \& Wong, H. (2014). Risk and credit change in Asian securitized real estate market. Habitat International, 43, 221-230.

https://doi.org/10.1016/j.habitatint.2014.03.008

Kindleberger, C. P. (1978). Economic response: comparative studies in trade, finance, and growth. Harvard University Press.

Lang, W., Chen, T., \& Li, X. (2016). A new style of urbanization in China: transformation of urban rural communities. Habitat International, 55, 1-9.

https://doi.org/10.1016/j.habitatint.2015.10.009

Lang, W., Chen, T., Chan, E. H., Yung, E. H., \& Lee, T. C. (2019). Understanding livable dense urban form for shaping the landscape of community facilities in Hong Kong using fine-scale measurements. Cities, 84, 34-45.

https://doi.org/10.1016/j.cities.2018.07.003

Lang, W., Long, Y., \& Chen, T. (2018). Rediscovering Chinese cities through the lens of land-use patterns. Land Use Policy, 79, 362-374. https://doi.org/10.1016/j.landusepol.2018.08.031

Lang, W., Radke, J. D., Chen, T., \& Chan, E. H. (2016). Will affordability policy transcend climate change? A new lens to reexamine equitable access to healthcare in the San Francisco Bay Area. Cities, 58, 124-136.

https://doi.org/10.1016/j.cities.2016.05.014

Li, J. (2013). What causes China's property boom? Property Management, 31(1), 4-21.

https://doi.org/10.1108/02637471311295388

Li, J. V. (2016). Housing policies in Hong Kong, China and the People's Republic of China (Working Paper No. 566). Asian Development Bank Institute. https://doi.org/10.2139/ssrn.2768070

Li, J., \& Chiang, Y. H. (2012). What pushes up China's real estate price? International Journal of Housing Markets and Analysis, 5(2), 161-176. https://doi.org/10.1108/17538271211225913

Li, J., \& Xu, Y. (2016). Evaluating restrictive measures containing housing prices in China: a data envelopment analysis approach. Urban Studies, 53(12), 2654-2669. https://doi.org/10.1177/0042098015594594

Li, J., Xu, Y., \& Chiang, Y. H. (2014). Property prices and housing affordability in China: a regional comparison. Journal of Comparative Asian Development, 13(3), 405-435.

https://doi.org/10.1080/15339114.2014.927747

Li, V. J., Cheng, A. W. W., \& Cheong, T. S. (2017). Home purchase restriction and housing price: a distribution dynamics analysis. Regional Science and Urban Economics, 67, 1-10. https://doi.org/10.1016/j.regsciurbeco.2017.08.002

Li, X. L. (2007). Analysis of the current high housing prices in China and possible policies (Master's thesis, Royal Institute of Technology, Stockholm, Sweden). Retrieved from https://docplayer.net/10779715-Analysis-of-the-current-high-housingprices-in-china-and-possible-policies.html

Lin, W. Y., \& Tsai, I. (2016). Asymmetric fluctuating behavior of China's housing prices. China \& World Economy, 24(2), $107-$ 126. https://doi.org/10.1111/cwe.12153

Lind, H. (2009). Price bubbles in housing markets: concept, theory and indicators. International Journal of Housing Markets and Analysis, 2, 78-90.

https://doi.org/10.1108/17538270910939574
Liu, H., \& Shen, Y. (2005). Housing prices and general economic conditions: an analysis of Chinese new dwelling market. Tsinghua Science and Technology, 10(3), 334-343. https://doi.org/10.1016/S1007-0214(05)70078-X

Liu, W. C. (2016). Do multiple housing bubbles exist in China? Further evidence from generalized Sup ADF tests. Journal for Economic Forecasting, 19(4), 135-145.

Lu, Y., Guo, H., Kao, E. H., \& Fung, H. G. (2015). Shadow banking and firm financing in China. International Review of Economics \& Finance, 36, 40-53.

https://doi.org/10.1016/j.iref.2014.11.006

McCarthy, J., \& Peach, R. W. (2004). Are home prices the next bubble? Economic Policy Review, 10(3), 1-17.

Meese, R., \& Wallace, N. (1994). Testing the present value relation for housing prices: should I leave my house in San Francisco? Journal of Urban Economics, 35(3), 245-266. https://doi.org/10.1006/juec.1994.1015

Mikhed, V., \& Zemčík, P. (2009). Testing for bubbles in housing markets: a panel data approach. Journal of Real Estate Finance and Economics, 38(4), 366-386.

https://doi.org/10.1007/s11146-007-9090-2

Pitros, C., \& Arayici, Y. (2016). How to identify housing bubbles? A decision support model. International Journal of Housing Markets and Analysis, 9(2), 190-221.

https://doi.org/10.1108/IJHMA-01-2015-0002

Ren, Y., Xiong, C., \& Yuan, Y. (2012). House price bubbles in China. China Economic Review, 23(4), 786-800. https://doi.org/10.1016/j.chieco.2012.04.001

Ren, Z. P. (2016). Global real estate bubble: cause, boom, bust, and hindsight (in Chinese). Retrieved from http://wallstreetcn. com/node/261365

Shen, L. (2012). Are house prices too high in China? China Economic Review, 23(4), 1206-1210. https://doi.org/10.1016/j.chieco.2012.03.008

Shih, Y. N., Li, H. C., \& Qin, B. (2014). Housing price bubbles and inter-provincial spillover: evidence from China. Habitat International, 43, 142-151. https://doi.org/10.1016/j.habitatint.2014.02.008

Shiller, R. (1981). Do stock prices move too much to be justified by subsequent changes in dividends? American Economic Review, 71(3), 421-436. https://doi.org/10.3386/w0456

Shiller, R. (1992). Market volatility. Massachusetts: MIT Press.

Shiller, R. (2013). Speculative asset prices (Nobel price lecture) (Cowles Foundation Discussion Paper No. 1936). https://doi.org/10.2139/ssrn.2391284

Shleifer, A., \& Vishny, R. W. (1997). The limits of arbitrage. The Journal of Finance, 52(1), 35-55. https://doi.org/10.1111/j.1540-6261.1997.tb03807.x

Sun, W., Zheng, S., Geltner, D., \& Wang, R. (2017). The housing market effects of local home purchase restrictions: evidence from Beijing. Journal of Real Estate Finance and Economics, 55(3), 288-312. https://doi.org/10.1007/s11146-016-9586-8

Tang, B. S., Wong S. W., \& Liu, S. C. (2011). Institutions, property taxation and local government finance in China. Urban Studies, 48(5), 847-875. https://doi.org/10.1177/0042098010363497

The People's Bank of China. (2016). Statistical reports on the loans destination of Financial institutions. Retrieved from http://www.pbc.gov.cn/rmyh/106866/index.html

Tsai, S. L., Kung, H. H., \& Haga, K. Y. A. (2015). Testing for multiple bubbles in the 35 large and medium cities of real estate price in China. Theoretical and Applied Economics, 22(4), 275-290.

Wang, S., Chan, S. H., \& Xu, B. (2012). The estimation and determinants of the price elasticity of housing supply: evidence from China. Journal of Real Estate Research, 34(3), 311-344. 
Wei, Y. G., Huang, C., Li, J., \& Xie, L. L. (2016). An evaluation model for urban carrying capacity: a case study of China's mega-cities. Habitat International, 53, 87-96.

https://doi.org/10.1016/j.habitatint.2015.10.025

Wei, Y. G., Lam, P. T. I., Chiang, Y. H., \& Leung, B. Y. P. (2010, June 1-2). Real estate private equity funds in China: a literature review. In Proceedings of the Second International Postgraduate Conference on Infrastructure and Environment (Vol. 2, pp. 155-165), Hong Kong, China.

Wei, Y. G., Lam, P. T. I., Chiang, Y. H., \& Leung, B. Y. P. (2014). The effects of monetary policy on real estate investment in China: a regional perspective. International Journal of Strategic Property Management, 18(4), 368-379. https://doi.org/10.3846/1648715X.2014.971087

Wei, Y., Lam, P. T. I., Chiang, Y. H., Leung, B. Y. P., \& Seabrooke, W. (2014). An exploratory analysis of impediments to China's credit control on the real estate industry: an institutional perspective. Journal of Contemporary China, 23(85), 44-67. https://doi.org/10.1080/10670564.2013.809978

Weng, Y., \& Gong, P. (2017). On price co-movement and volatility spillover effects in China's housing markets. International Journal of Strategic Property Management, 21(3), 240-255. https://doi.org/10.3846/1648715X.2016.1271369

Wind Database. (2016). Retrieved from https://www.wind.com. $\mathrm{cn} / \mathrm{en} / \mathrm{edb} . \mathrm{html}$

Wu, J., Gyourko, J., \& Deng, Y. (2012). Evaluating conditions in major Chinese housing markets. Regional Science and Urban Economics, 42(3), 531-543. https://doi.org/10.1016/j.regsciurbeco.2011.03.003

Wu, J., Gyourko, J., \& Deng, Y. (2015). Real estate collateral value and investment: the case of China. Journal of Urban Economics, 86, 43-53. https://doi.org/10.1016/j.jue.2014.12.006

$\mathrm{Wu}, \mathrm{X}$. (2015). An introduction to Chinese local government debt. Retrieved from http://gcfp.mit.edu/wp-content/uploads/2013/08/Policy-Report-of-Chinese-Local-GovernmentDebt-final.pdf

Xie, Y., \& Jin, Y. (2015). Household wealth in China. Chinese Sociological Review, 47(3), 203-229. https://doi.org/10.1080/21620555.2015.1032158

Xu, X. E., \& Chen, T. (2012). The effect of monetary policy on real estate price growth in China. Pacific-Basin Finance Journal, 20(1), 62-77. https://doi.org/10.1016/j.pacfin.2011.08.001
Yang, J., Yu, Z., \& Deng, Y. (2018). Housing price spillovers in China: a high-dimensional generalized VAR approach. Regional Science and Urban Economics, 68, 98-114. https://doi.org/10.1016/j.regsciurbeco.2017.10.016

Yiu, M. S., \& Jin, L. (2012). Detecting bubbles in the Hong Kong residential property market: an explosive-pattern approach (Working Paper No. 1). Hong Kong Institute for Monetary Research. https://doi.org/10.2139/ssrn.1988839

Yiu, M. S., Yu, J., \& Jin, L. (2013). Detecting bubbles in Hong Kong residential property market. Journal of Asian Economics, 28, 115-124. https://doi.org/10.1016/j.asieco.2013.04.005

Yu, H. (2011). Size and characteristic of housing bubbles in China's major cities: 1999-2010. China \& World Economy, 19(6), 56-75. https://doi.org/10.1111/j.1749-124X.2011.01266.x

Yu, H. (2015). The spillovers and heterogeneous responses of housing prices: a GVAR analysis of China's 35 major cities. Journal of the Asia Pacific Economy, 20(4), 535-558. https://doi.org/10.1080/13547860.2015.1045527

Yu, H., \& Huang, Y. (2016). Regional heterogeneity and the trans-regional interaction of housing prices and inflation: evidence from China's 35 major cities. Urban Studies, 53(16), 3472-3492. https://doi.org/10.1177/0042098015617882

Zhang, Y., Hua, X., \& Zhao, L. (2012). Exploring determinants of housing prices: a case study of Chinese experience in 19992010. Economic Modelling, 29(6), 2349-2361. https://doi.org/10.1016/j.econmod.2012.06.025

Zhou, W. X., \& Sornette, D. (2003). 2000-2003 real estate bubble in the UK but not in the USA. Physica A: Statistical Mechanics and its Applications, 329(1), 249-263. https://doi.org/10.1016/S0378-4371(03)00600-9

Zhu, X., Li, Y., Wei, Y., Zheng, X., \& Xie, L. (2019). Temporalspatial characteristics of urban land use efficiency of China's 35 mega cites based on DEA: decomposing technology and scale efficiency. Land Use Policy, 88, 104083. https://doi.org/10.1016/j.landusepol.2019.104083

Zhu, X., Zhang, Z., Wei, Y., Li, Y., \& Zhao, H. (2019). Measuring the efficiency and driving factors of urban land use based on the DEA method and the PLS-SEM model - a case study of 35 large and medium-sized cities in China. Sustainable Cities and Society, 50, 101646.

https://doi.org/10.1016/j.scs.2019.101646 